\title{
EVENTS OF THE REVOLUTION OF DIGNITY ON THE PAGES OF MODERN UKRAINIAN LITERATURE
}

\author{
Kobylko N. A., Honcharuk O. M.
}

\section{INTRODUCTION}

In a modern literary process, the revolution of dignity occupies an important place. Most completely the Maidan found a review in poetry works, publishing houses engaged in the conclusion of anthologies, whose authors were as well-known writers and beginner poets. Subsequently, prose works were printed. They are characterized by genre variety and combination of various styles: journalistic, artistic, epistolar. Initially, the Maidan literature had the look of Facebook notes, comments, memoirs of activists, volunteers, reporting and documentary editions. The boom of modern Maidan literature, which we observe today, shows that the topic of the revolution and war is tangent to the problems of culture, the desire of artists to a comprehensive and impartial rethinking. The writers are truthfully reflecting the events of Maidan, the direct participants of which they were, exposing the myth of the friendship of the peoples, laid by previous epochs. The authors are building a new model of Ukrainian culture of the 21 'st century.

Literary critics are increasingly referring to the topic of the revolution. So, Yaroslav Polishchuk in his scientific intelligence described Euromaidan as an event in three its projections - public, media, literary. Oksana Pukhonska investigated the interpretation of posttotalitarian memory in modern literature. Nina Herasymenko and Olga Bashkirova made a review of novels about Maidan and the war of Ukrainian women-writers, in particular Halyna Vdovychenko, Svitlana Talan, Lesia Orliak, Halyna Kyrpa, etc. Literature specialist Halyna Horishna analyzed the artistic features of Maidan's poetry. Novels of Luko Dashvar "The Cover" and Julia Iliukha "Eastern Syndrome" in literary criticism are mentioned sporadically, so the study of the artistic specificity of these works is actual.

The purpose of our work is to study the artistic features of the Maidan prose "The Cover" by Luco Dashvar and "Eastern Syndrome" by Yulia Iliukha. To achieve the goal we are to solve some tasks. 1. To investigate 
the impact of the revolution of dignity for the development of modern Ukrainian literature. 2. To find out the composite features of the Dashvar's novel "The Cover". 3. To consider the role of Maidan in determining the life benchmarks of the heroes of Luco Dashvar's prose. 4. To analyze the artistic world of Yulia Iliukha's novel "Eastern Syndrome". 5. To describe the Maidan as a prerequisite of the RussianUkrainian war in the Donbass.

Research methods are due to the purpose of work and the nature of the tasks. The leading method is the method of typological analysis, which allows you to identify the features of the topic of the revolution of dignity in literary works. Descriptive method is used during the study of historiography of the genre variety of literature. The principles of hermeneutical and systematic approaches to the comprehension of historical and literary phenomena, analyses of artistic and stylistic structures of Luco Dashvar and Yulia Iliukha's prose are also involved. The paper used elements of the cultural and historical method, as well as traditional contextual and description-analytical approaches to the study of artistic literature.

\section{Influence of the revolution of dignity on the development of modern Ukrainian literature}

In the modern literary process, the theme of Euromaidan and the Russian-Ukrainian war in the Donbass does not lose its relevance. At the same time, it is quite wide and multifaceted. The writers were among the activists, so the first truths to describe the events of the turning point for the Ukrainian society in 2014. Their works are distinguished by exaggeration, and therefore return the trust of the people to literature. This, in turn, leads to both the genre variety and the specifics of forms of life. Literary specialist Ya. Polishchuk notes, "The voice of the writer again became the highest extent, which caused a flurry of various speeches - oral (on the Maidan lectures and literary readings were presented), printed (mainly in the press, but also distributed in the form of postcards), media (copied through a variety of network resources)" 1 . At that time, there were many anonymous works, whose authors appeared later. Popular poetry was imbued with feelings of pain, pride, invincibility, willingness to go to the end. It reflected the emotions of the Maidan people and was close to everybody, so it was perceived as folk.

\footnotetext{
${ }^{1}$ Поліщук Я. Ефект Євромайдану і література. Слово і час. 2015. № 10. С. 12.
} 
Literature of the revolution of dignity is actively replenished with journalistic and artistic works. The circle of writers expands and covers professional writers, journalists, bloggers, activists and volunteers. The first successful attempts to reflect the events of 2013-2014 can be traced in the genre of non-fiction and journalism. This is primarily a book of reports, interviews with eyewitnesses, investigation. In our opinion, "Maidan. The Untold Story" by Sonia Koshkina, "Euromaidan [Ordinary Heroes]" by Natalia Huk, a book-album "The 94 Days. Euromaidan with eyes of TSN" deserve special attention. Reproducing events of the revolution of dignity, authors resort to different methods. Some pages of their works focus on the chronology and geography of Maidan, the others deepen into the inward life of the main characters.

In addition to journalistic and documentary works, a modern literary process is refilled with artistic. First, revolutionary poetry appears. The world saw such anthologies as "The Heavenly Hundred" and "Euromaidan. Lyrical Chronicle". We can not leave a collection of "Euromaidan: Chronicle of Feelings", whose authors are the considered writers: Serhiy Zhadan, Taras Prokhasko, Ihor Tsyperdiuk, Yuriy Andrukhovych, Yuriy Vynnychuk. According to Ya. Polishchuk, the artists submit a change in the perception of the revolution in chronological order - from the first romantic sentiments to tragic completion. At the same time, every writer is distinguished with a creative manner, and therefore, various views on the events of Euromaidan are collected.

Artists also appeal to the topic of the dignity revolution in prose genres. So, the literature is replenished with new novels, essays and chronicles. Many books are printed in two linguistic versions Ukrainian and Russian. In our opinion, the popularity of bilinguistic books is due to the fact that the Maidan, as well as the Russian-Ukrainian war in the Donbass, united people that differ in language, nationality, religion, but persecute one goal - the creation of a free European country. It is worth mentioning the novel "Ilovaisk" by Yevhen Polozhiy and the story of Mark Rudnevych "I am from the Heavenly Hundred".

Some writers describe the Euromaidan events as second-handed plot lines, and the work complicates with other microstrips. This way they exacerbate the reader's attention not only on the problems of national dignity, self-sacrifice, but also prompt to reflect on good and evil, the price of truth, the purpose of human existence. From this point of view the novels of Victoria Amelina "Syndrome of November" and Luko 
Dashvar "The Cover" are very interesting. The revolution is the place of awareness of its essence, and the end of mental toils.

We suppose that various aspects of the Maidan are best disclosed in such genres as a chronicle and diary. Artists focus on documenting events, adhering to chronology, fixing the evidence of participants. Books are also in the language of the story. So for the literary project of Oksana Zabuzhko "The Cronicle of Eyewitnesses. Nine Months of Ukrainian Resistance" is characterized by expressive broadcasting, surzhik, repetitions, and "Diary of Maidan" by Andriy Kurkov is distinguished by restraint and detail. The writers submit numerous comments on the political situation in the country, the intentions of the participants of the revolution. With these book details, the national coloring of Euromaidan events pass.

The revolution of dignity greatly influenced on the development of modern Ukrainian literature. Writers, literary critics reinterpreted the role of the word in the public life of the country. For many artists, the events of Euromaidan opened new opportunities for creativity. New literary genres have appeared, the artistic features of epic and lyrics have expanded. We can assert that today the theme of the revolution of dignity, as well as the Russian-Ukrainian war in the Donbass, is not exhausted. It also included a catalyst for the development of literature, its renewal.

At the same time, among literary critics there is no unanimity in terms of the quality of art works, because they were writing as a spontaneous response to the events, passed the sense of Maidan people. Many works require a thorough literary treatment. This is primarily Facebook notes and diaries. The advantage of such a type of "new literature" is its affinity with a mass culture. But if we consider the prospect of these works, then artists should work on art forms.

Literature about the revolution of dignity is actively replenished with hybrid genres that arise on the verge of artistic and journalistic styles. So notes and comments of journalists, blogs and reflection of activists are processed by writers and reach the reader in the form of essays. An example of mixing genres and styles is the cultural and artistic project of Antin Mukharskyi, active participants of which are artists, musicians and performers $^{2}$. The postmaidan period of development of Ukrainian culture is characterized by an update of reflection techniques, experimentation,

2 Поліщук Я. Література майданного гарту. Літературний проиес: методологія, імена, тендениії : збірник наукових праць (філологічні науки). 2015. № 6. C. 174. 
expression. Consumers of such a culture are young people, and therefore, works correspond to the requests of modern society.

A researcher O. Pukhonska proposes to consider the literary process of the 21'st century in an aspect of traumatic memory. In her scientific exploration "Posttotalitarian memory in modern literary interpretation: Ukrainian version" she allocates three stages of its formation: 1) artistic works of the second half of the 1990's; 2) artistic works of the first decade of the 2000's; 3) literature after the revolution of dignity. The tragic events of Euromaidan identified the main vectors of fiction. The first - works about the revolution ("The Cover" by Luko Dashvar, "Under the Wings of the Great Mother" by Stepan Protsiuk, "Fire Winter" by Andriy Kokotiukha), the second - the novels about the war in the east of Ukraine ("Ilovaisk" by Yevhen Polozhiy, "Eastern Syndrome" by Yulia Iliukha, "The Mariupol Process" by Halyna Vdovychenko, "The Black Sun" by Vasyl Shkliar). Due to the reception of chronological mapping, writers appeal to national memory, rethinking the Soviet past. "The events of the revolution of dignity are necessarily perceived in the context of a long struggle against its ghosts, presenting not only in the model of behavior of political elites, but also necessarily in the consciousness of society". ${ }^{3}$ Literature specialist O. Pukhonska believes that the main merit of the Maidan literature is finding a mental home, that is, the final clearing of national memory.

The war in the Donbass, as a continuation of Euromaidan, is depicted through the prism of mental separation: Western and Eastern Ukraine, and hence, "ukrops" or "bandera" and "civil guardsmen". We trace a clear division into your own and alien within the same country. We think this limit is acutely felt as in the novels about the war, and about the revolution of dignity. Alien is not only an enemy, which seeks territorial distinction, but also an indifferent observer.

Modern Ukrainian literature certifies the process of restoring the traumatic memory of the past and the creation of the memory of the present. Writers are trying to get rid of the burden of Soviet myths. They are not aesthetizing reality, do not give their own evaluation, but confusing the reader to reflection: whether to continue to live the ghostly ideals of the past, or to create their national space.

3 Пухонська О. Посттоталітарна пам'ять у сучасній літературній інтерпретації: українська версія. Науковий вісник Уэсгородського університету. Серія «Філологія». 2016. Вип. 2 (36). С. 216. 
On analyzing the Maidan and military prose of the authors of men and women, it is possible to distinguish its features: firstly, in a women's prose there is a strong emotional stream, while men focus on the detail of events. Secondly, women create live human characters, and men mostly describe the course of events. However, in its set, artists give a wide panorama of events of the end of 2013 - early 2021. According to the researcher O. Kotsarev, the introduction of war and revolution in the cultural process creates new literary archetypes.

Consequently, the revolution of dignity is an extremely important event of independent Ukraine. It clearly outlined the limits of the transition period of social and cultural development. The Maidan became the basis for the formation of a genre variety of fiction literature. Almost at once the Maidan poetry has appeared, concluded anthology. Prose works suffered more transformations: from notes, blogs, comments on social networks to memoir literature and novels. Today the theme of the revolution of dignity, as well as the war in the east of the country, is not fully disclosed. In literary history, there is no single approach to analyzing the artistic work of writers. However, it does not go to the fact that the Maidan military prose occupies its niche in a modern Ukrainian literary discourse.

\section{Life collisions of heroes on the background of Maidan in Luko Dashvar's novel "The Cover"}

Today, Luco Dashvar is considered to be the most successful Ukrainian writer. Already her first novel "Village is not People" became the laureate of Word Coronation Prize - 2007, the next ones "Milk with Blood" (2008) and "RAI.Center" (2009) were recipients of this competition. In the autumn of 2010, Luko Dashwar gets an honors "Golden writer of Ukraine", and her works are printed over 100 thousand edition. The author writes sharply and piercing, psychologically and sensually. Her heroes are not possible not to sympathize, because it is a collective image of ordinary people with their problems, emotional searches, faith in a better life.

In 2015, the world saw Luco Dashvar's novel "The Cover", written as a review of the events of Euromaidan. The writer develops two story lines, at first glance, are not interconnected. The first is historical. In our opinion, this plot line appears in two time segments: the biography of Yarema Dorosh, a Cossack of Chernihiv Regiment and the stormy events of the revolution of 2013-2014. The second is romantic: the love story of Mariana and Yarko during the Maidan. The novel "The Cover" 
represents the literature of postmodernism. Luko Dashwar depicts an independent personality that can overcome all the difficulties on his way. This is both Mariana in search of a forgotten Dorosh family, and Yarko with faith in the opportunity to change the country. The author attracts such elements of myth as a treasure and curse; combines different styles (epistolary and artistic).

The characters of the main images are issued taking into account social factors and gender features. So, the image of Mariana fully corresponds to postmodern trends. According to Yu. Chushenko, the crisis of being affected the moral state of the girl, she is confused, makes uncontrolled deeds, "Mariana seems to have a sign on the forehead Looser! All twenty-seven years of her life just collects the failures". ${ }^{4}$ She is at the crossroads: the choice of specialty, search for decent work, creating her own family. In contrast, the image of Yarko Luko Dashvar submits to the traditional key with the corresponding masculine lines such as courage, self-sufficiency, stability, dominance, "Closer he looked older - middle height, strong - not eighteen, no, but not twenty seven! Short black hair with a whirlwind over a forehead, under thick black eyebrows, mocked adult eyes, as if all in the world seen $<\ldots>$. ${ }^{5}$ Yarko is still a student, but with a clear civil and life position. He is a supporter of Maidan, never hides from danger, one of the first injuries from asset activists. Immediately after the storm events in Kyiv, he mobilized to the east of Ukraine. Yarko is a faithful friend, an inspiration for many, but at the same time his soul wraps loneliness, "Loneliness is the Japanese sun. Hot soul in infinite indifferent white space". 6 The guy was a supporter of Quattrocento philosophy. He believed that "everyone has the right to engage in free creativity, and the advantage of human is in its dignity". 7 Perhaps that is why on Maidan Yarko felt native, needed.

The peculiarity of Luco Dashvar creative manners are names of books, which contain double interpretation. In the Ukrainian language dictionary, the following definition is given, "Under the cover a) (whose) using someone's intercession; b) (what) masking something;

\footnotetext{
${ }^{4}$ Чушенко Ю. Концепція особистості жінки в сучасній постмодерній прозі : дипломна робота. URL: http://93.183.203.244:80/xmlui/handle/ 123456789/6438.

5 Дашвар Люко. Покров : роман. Харків : Книжковий клуб «Клуб сімейного дозвілля», 2016. С. 108.

${ }^{6}$ Там само. С. 126.

7 Там само. С. 134.
} 
c) (what) using something as a cover". ${ }^{8}$ The writer interprets the name and an old crooked-necked woman says, " $<\ldots>$ when a person knows his own ancestors, therefore, it is not necessary to help, because the native blood is a cover, protection". 9 If you do not remember your past, what future will you be able to build? It can be assumed that the blood of glorious Dorosh, which flows in Yarko, helped him to stand on the Maidan, because he is a worthy descendant of the Great Cossack. The ancestors did not leave Mariana, showed the right way.

The novel "The Cover" is distinguished with its composition, too. Artistic time and space are integral structural elements of any literary work. The chronotope emphasizes the unique worldview of the artist, his definite system of values. According to M. Bakhtin, the main features of time and space are their interconnection and structural unity, "The time thickens here, condenses, becomes artistic-visible. The space is intensified, retracted in the movement of time of a story plot". ${ }^{10}$ In the novel Luco Dashvar violates time-spatial attitudes, modern events are intertwined with the past. The reader is in Kyiv, where the revolution of dignity of 2014 is gaining, then, it immediately falls into Doroshivka of 1843. The image of Baba Kryvoshyikha (an old crooked-necked woman), a folk healer, unites history and modernity because people always needed help, "To whom I can help, to the same I go". ${ }^{11}$ She acts as a template of family values, people's customs, as a keeper of the ancient history of Doroshivka village. Once more, the reader meets Kryvoshyikha on the Maidan, " $<\ldots>$ appeared among us like snow on heads when the boys fell ill. And disappeared without asking". ${ }^{12}$ She is a living history witness to not one generation.

In her novel Luco Dashvar uses various composite techniques to associate the time planes. This is a retrospection (searches in the archives the information about the descendants of the Cossack Yarema Dorosh to the seventh generation, mention of an old woman Nata about her ancestors), and visions (Alex and Kurt's love), and letters from the past

\footnotetext{
${ }^{8}$ Словник української мови : Академічний тлумачний словник (1970-1980). URL: http://sum.in.ua/s/pokrov.

${ }^{9}$ Дашвар Люко. Покров : роман. Харків : Книжковий клуб «Клуб сімейного дозвілля», 2016. С. 355.

10 Бахтин М. Формы времени и хронотопа в романе : Очерки по исторической поэтике. Москва : Просвещение, 1989. С. 10.

${ }^{11}$ Дашвар Люко. Покров : роман. Харків: Книжковий клуб «Клуб сімейного дозвілля», 2016. С. 7.

12 там само. С. 224.
} 
(the will of Perpetuia). The composition has a peculiar framing, which, in our opinion, reveals the idea of a novel. It is built on the opposition of life-death. "At black night of the year of 1843 in a smoking own estate with windows into the autumn naked garden sixty-year-old Yarema Dorosh was agonizing $<\ldots>$ ". ${ }^{13}$ The novel begins from these lines. The death of the protagonist the writer makes the starting point of life vital of all characters. At the end of the work Dorosh's soul appeared, "And from the sky Yarema's battle wounded, crippled, but adamantine eternal soul was looking. Smiling tired and happily". ${ }^{14}$ The soul was watching the birth of a new life, and therefore we can argue that the ancestors began to protect their descendants, their cover.

Another important part of the novel is the years on which the author accents. Individual periods are described without details, but symbolic acts 1914 and 2014, the beginning of the First World War and the Russian-Ukrainian War in the Donbass. The events of the revolution of dignity are relocated with the stormy 1918 . The writer emphasizes that the chronotope changes, but not human qualities. The history of heroes becomes part of the history of the genus, and is the whole generation and country. The past helps to find answers to the question of the present.

The main storyline of Luco Dashvar's novel "The Cover" is the events of Maidan in 2014. The author describes not only the chronology of the revolution of dignity, but also reveals its perception of various people. Some remain indifferent observers, others defend its ideals, but someone's life is dramatically changing. In addition, in its nature, the novel "The Cover" is postmodernist, it can be considered quite feminine. The writer focuses on heroins (Mariana, Aida, Stanislava), shows the way of their evolution, changing personal and social priorities.

Initially, Mariana indifferent perceived events on the Maidan, hostile to the participants of the revolution of dignity, "Mariana was not on the Maidan since the square became the center of rebellion and until a peaceful resistance. She was walking from Besarabka along Khreshchatyk, looking stressfully and hostile, as if all here had to be like those from Poltava, who occupied Yarko's room, - empty, brazen, unlearned, who came from everywhere to finally collectively assemble what they wanted, and did not dare to make earlier $<\ldots>$ ". ${ }^{15}$ First the Maidan hampered the

13 Там само. С. 5.

14 Там само. С. 378.

15 Дашвар Люко. Покров : роман. Харків : Книжковий клуб «Клуб сімейного дозвілля», 2016. С. 193. 
girl physically (a crowded city, closed metro station, paralyzed movement), and then Mariana felt that it pressed morally (could not remain aloof when others needed her help). The Maidan was divided into two camps: people with an invincible faith that can change the course of history for the better (father, Polia, Yarko, Aurora, Bidjo) and those who pursued their own interests (Shuliak, Khotynskyi). We are sure, the first losses and sacrifices changed her mind. So, in mysterious circumstances, Polia's friend, a student Ihor Kornilov disappears, his father decides to finish his life with suicide, because he did not justify the trust of Maidan people, lost funds collected on tents. But the greatest shock was the deaths of Halynka, Gotsyk and Makar, "On February, 19 , after a day of watching near the crippled volunteers, shaking from fatigue and horror, Mariana came out in a gray dawn. House of Trade Unions was burning. People were lying on the cold ground". ${ }^{16}$

Events of the revolution of dignity are revealed again through one female image - Polia, the girl, Mariana's girlfriend. She was on the Maidan since the beginning of its organizing. Together with Ihor shouted slogans, distributed agitation. Polia for a long time combined the usual life, work in a hospital and evening visits to Maidan. The views on the situation in the country have changed fundamentally after the conflict of peaceful activists with security forces, " $<\ldots>$ face in blood, tore coat, bruise on armlets. Trembling, looking at the floor, as if all the points of reference and all the answers are there". ${ }^{17}$ A student Ihor Kornilov was the first victim of the revolution of dignity, and Polia became an unchanged nurse of Maidan. The events of stormy 2014 hardened character, made people braver, pushed to unusual deeds, but the daily contemplation of the wounded and killed mates broke the mind, especially the young people. Polia was not exception. To dull the horrors and nightmares helped the vodka, "Polia came, thinned even more, the hair is not cleaned, but not the main thing: the eyes are lustreless, smell of alcohol". ${ }^{18}$

Quite interesting Luco Dashvar depicts Aida. A woman lives by his own interests, demonstrates the scorn to the activists of Maidan, among which was her husband Valentin. For the sake of material abundance leaves the family and comes to the proposal of Shuliak. Selfish in nature, Aida, however, can not reconcile that the lover's wealth - a successful deal with

16 Дашвар Люко. Покров : роман. Харків : Книжковий клуб «Клуб сімейного дозвілля», 2016. С. 251.

${ }^{17}$ Там само. С. 45.

${ }^{18}$ Там само. С. 281. 
finances of Maidan people. For Slavko Shuliak, the revolution became a place of profits. And Aida gave amassed back to genuine owners, because she came to awareness that the main value in life is a family.

On the pages of the novel "The Cover" there are men's images. Active supporters of dignity revolution are Yarko, Aurora and Bidjo. We can argue that Luko Dashwar created a combined male image. The Maidan not only united young men, but also made them sworn-brothers. The revolution they understood as Quattrocento, "This is when people finally begin to feel people. As we have now $<\ldots>$. 19 The friends stood together on the Maidan, defended the East of Ukraine from separatists. Luko Dashvar gives the sharpness of the image of Bidjo, Georgian in origin, which dies in the Russian-Ukrainian war, but remains faithful to his ideals. The sense of national freedom during the period of dignity revolution woke up in emigrants, too. The owner of the law firm Peter Kravchuk leaves Canada and becomes part of the Maidan, "Heroes of Maidan have not yet guessed - for a month and a half a hundred fell down, thousands crippled forever, and in all living on the heart there would be a rude scar like a police baton. Who scares tomorrow - today does not live, and the Maidan lived, inspired and stubbornly spilled around the waves of wishing will, as dignity $<\ldots$. ". ${ }^{20}$

Thus, Luco Dashvar's novel "The Cover" is multifaceted, rises the problems of patriotism, loyalty of duty, and love, betrayal, human values. The plot lines are interwoven, the images of the main characters are undergoing changes. Immersion in Ukrainian history, mythology helps to understand the mood of the Maidan activists, the main values that the revolution of dignity defended. The younger generation sought freedom of will as "the root cause of the rise of the human spirit". Using the reception of contrast to positive and negative, life and death, Luko Dashwar revealed the psychology of the main characters.

\section{Yulia Iliukha's novel "Eastern Syndrome" - the story of people who returned from the war with the body, not a soul}

Yulia Iliukha entered the Ukrainian literary process as the author of small prose works and books for children. However, the novel "Eastern Syndrome" became significant, which was marked by the second prize of the Word Coronation Prize - 2018. The writer worked over it during a

19 Дашвар Люко. Покров : роман. Харків : Книжковий клуб «Клуб сімейного дозвілля», 2016. С. 134.

${ }^{20}$ Там само. С. 199. 
year, but did not receive approvals from publishers. It took almost two years until the novel met its reader. In an interview for the book blog "Yakaboo", Yulia Iliukha explains why she decided to write a book about the war, "For me it was quite logical and naturally, because since the summer of 2014 I was a volunteer of ATO, we had a group of likeminded people called "Real Help to the Military". ${ }^{21}$ The novel "Eastern Syndrome" is an artwork with real events and prototypes. The author interprets the images, submits her history of their lives, attracting separate facts of biography of real people. So, prototypes have Turk and Rock. They were a writer's friend who lived in Luhansk, and then went as a volunteer to the 92'nd brigade, and a Russian paramedic, which is now serving in the Armed Forces of Ukraine. Fully invented in the novel is Lawyer character.

In the name of the work Yulia Iliukha uses the term to indicate traumatic experience, rather, a mental disorder that arises in the people who have passed the war. We know "Vietnamese syndrome", "Afghan syndrome", "Combat syndrome". Since the beginning of the RussianUkrainian war in the Donbass, the concept of "Eastern syndrome" includes. In the novel, the author deepens the inner world of heroes, their mental state, submits the chronology of events in 2013-2015. In our opinion, the writer aimed at not to reproduce a war in the east, but to trace its prerequisites and imprint on the fate of the participants. One heroes can overcome the "Eastern syndrome" and return to peaceful life, and the others are morally remained in the Donbass.

It is also interesting the writer's interpretation of the war. Her heroes are in the east of Ukraine for various reasons, Lawyer runs away from family problems, Turk - for the sake of revenge, Rock - in search of a new life. It is no coincidence that the characters are representatives of different regions, which is also perceived as opposition: Vasia is from Western Ukraine, Max is from Donbass, Tania is from Russia. The novel also has composite features. Separate sections are presented as a biography of the characters, Maidan and the war are mentioned fragmentary. Despite the fact that "Eastern Syndrome" to a greater extent is a book about the Russian-Ukrainian war, there are no bloody scenes and battles. We can indicate that there is the difference between male and female military prose. The main emphasis writer has made on the lives of

21 \#Під_Арсенал. Юлія Ілюха: ««Східний синдром»- це вигадана історія, яка перегукується 3 долями тисяч ветеранів ATO». URL: https://blog.yakaboo.ua/ru/shidnyi-syndrom/. 
heroes after the ATO, their ability to control the manifestations of a mental disorder. The author notes, "I would like to focus on this problem - the problem of returning veterans to peace life". ${ }^{22}$

In the novel, the plot is events of the beginning of the RussianUkrainian war. However, in the canvas of the work harmoniously interconnected the lives of the heroes to the revolution of dignity, which are perceived as separate microthemes. The writer uses retrospection, visions and sleep. Also, the topos of the novel is interesting. Events unfold in Kharkiv, Luhansk, Donetsk, Kyiv, Omsk, Istanbul. Accordingly, the writer reproduces the color of these cities and their inhabitants.

Yulia Iliukha makes Vasia Suprunchik (Lawyer), Max Shilov (Turk) and Tania Sukhareva (Rock) as the main characters of the novel "Eastern Syndrome". The author gives her heroin masculine traits, courage, hardness of thoughts, desperation. We can argue that Max and Tania experienced stronger spiritual injuries than Vasia, and therefore, after the war they were able to realize.

Everyone has his own life principles and ideals. So, Vasia Suprunchik did not go too much about his future, because it became used to all the others. At first it was his parents, then - his wife, "The word "nepotism" Vasia knew since childhood. He went out of turn to a doctor, had good grades in school, went to the gym and traveled in minibuses free of charge". ${ }^{23}$ The guy from Rivne had his own feature - in Russianspeaking Kharkiv spoke Ukrainian. The uncertainty and dumping of the hero are marked two stages of life: after the army and ATO. Vasia's image is characterized by feminine character traits: softness, compliance, impossibility to take a serious decision. Being in the study group the hero for a long time did not realize that the war is true, and former tractor or taxi drivers, builders, programmers - the basis of the Ukrainian Army. His ideological beliefs and patriotic thoughts Lawyer formulated as follows, "Someone came here voluntarily, for someone, as he decided, it was too late to run away, someone was hiding, but finally was found". 24 The war did not bring relief, because at home he was unnecessary: the daughter was afraid, his wife found the other, peaceful residents

\footnotetext{
22 \#Під_Арсенал. Юлія Ілюха: ««Східний синдром” - це вигадана історія, яка перегукується 3 долями тисяч ветеранів ATO». URL: https://blog.yakaboo.ua/ru/shidnyi-syndrom/.

23 Ілюха Ю. Східний синдром : роман. Харків : Книжковий клуб «Клуб сімейного дозвілля», 2019. С. 13.

${ }^{24}$ там само. С. 46.
} 
scornfully treated everyone in military uniform. The only solace was meeting with combat comrades, where he was full of memories. With thoughts he remained in the Donbass. It can be argued that the death of the hero at the end of the novel was an artistic plan. The author makes it as one of the possible consequences of "eastern syndrome".

The full opposite to Lawyer is Turk, a successful businessman, a fully realized person. His work achieves financial stability, accepts balanced decisions, believes that the worthy future can be built in their homeland, "Finally returning to Donbass, Maxim immediately bought an apartment in a new building $\langle\ldots\rangle$ As long as he was engaged in the opening of his own small IT-firm, Olia with enthusiasm took place their love nest". ${ }^{25}$ But the dreams are not destined to come true. Max was brutally beaten by the "guardsmen" and illegally absorbed the property to the development of the DPR, but the worst - shot his beloved. By means of mass shot "guardsmen" wanted to demonstrate the power of the newly proclaimed republic. Turk went to the war to take revenge, muffle the mental wound. Yulia Iliukha depicts an extremely courageous and strong personality. He was able to survive the loss of his beloved, and therefore, overcomes "eastern syndrome".

On the pages of the novel, along with men's images, a woman is depicted. Running away from a husband-tyrant, Russian Tania is in our war. The writer sympathizes with her heroine, because she did not know since childhood to parental care, a family comfort, and did not feel female happiness with her husband Sergei, who caused her moral and physical pain. "In constant fear and feeling of own insignificance, the slow tortoise suggested ten years of marriage. $<\ldots>$ The divorce has not even thought of Tania, it was used to exist such a way, in the role of captive, victim, which is not responsible even for her own life". ${ }^{26}$ However, daring to escape, a woman decides to get lost in the revolution of dignity, which only gained momentum. In search of new herself Rock is in the Donbass. The writer gives the heroine feminine and masculine traits, which help her to overcome "eastern syndrome".

Consequently, the theme of the war in the novel of Yulia Iliukha "Eastern Syndrome" is present, but not the main one. Events in the east of Ukraine encounter heroes whose lives are dramatically different. Maybe in other circumstances they would never meet. The author

${ }^{25}$ Ілюха Ю. Східний синдром : роман. Харків : Книжковий клуб «Клуб сімейного дозвілля», 2019. С. 66.

${ }^{26}$ Там само. С. 112. 
focuses on the psychological change of characters, their strength will return to peaceful life.

In the novel "Eastern Syndrome", Yulia Iliukha expands the topos, describes various regions with their social and political tempers. The writer emphasizes her attention on events preceding the RussianUkrainian war in the Donbass. The main characters are representatives of Western and Eastern Ukraine. Mentally they are different. The first awareness of his features comes at the university. So, Vasia Suprunchik from a small Ukrainian-language Rivne arrived to Kharkiv, and Maxim Shilov does not understand the lectures in Ukrainian in Kyiv, because he grew up in the Donbass.

Maidan dashed in the capital, but found its supporters and in other cities. We may notify that the novels "The Cover" by Luko Dashvar and "Eastern Syndrome" by Yulia Iliukha pass the revolutionary mood of the whole country. So, the first writer focuses on the description of the events of the revolution of dignity in Kyiv, and the second reproduces the contrast of the perception of the Maidan in the inhabitants of Kharkiv and Donbass.

"Lonely and unhappy Vasia was wandering around a frozen city, until it stops to feel hands and feet from cold. Near the monument to Shevchenko noticed a group of people with yellow-blue flags". ${ }^{27}$ It was Kharkiv Maidan. Interestingly, among the activists Lawyer felt good. However, he does not detect hardness of character here: after work came to the monument to Shevchenko, and then quickly run home. He was a supporter of changes in the country, but did not shout the slogans. "February came with battles. Live on TV broadcast smoke, blood and death". ${ }^{28}$ Moreover, nobody knew that peaceful protests of Maidan people would become the beginning of the war.

Rather large print Euromaidan imposed on Kharkiv. The area before the administration was divided into two hostile camps - Euromaidan people, yesterday's schoolchildren wearing balaklavas, and anti-Maidan people. "Over the administration, several hundred meters from Vasia's house, a tricolor loomed. In the city it became dangerous to walk with a ribbon of colors of the Ukrainian flag. The ribs and noses were broken for it, punched heads and achieved legs". ${ }^{29}$ The tensity grew, and the

27 Ілюха Ю. Східний синдром : роман. Харків : Книжковий клуб «Клуб сімейного дозвілля», 2019. С. 36.

28 Там само. С. 39.

29 там само. С. 40. 
inhabitants covered hysteria. Kharkiv stood, KhPR did not take place. The beginning of the anti-terrorist operation (ATO) was perceived as a cleaning of the territory from the rebels, "After all, it can not be so that Kharkiv kept, and Donbass could not!" 30

In another way, the residents of the East of Ukraine perceived the revolution. In Donetsk it was possible to see the groups of people with yellow-blue flags, and followed by others - with George ribbons. "The capital of Donbass became similar to a porcupine, ready to torture to skip and put needles". ${ }^{31}$ At that time, Max was most affected by familiar, educated and wealthy people of all ages that hated Europe, and all hopes were raised on Russia. The point of inevitability can be considered the first spilled blood for the formation of the DPR. About better life in Russia told athletics with bats. Those were the most effective methods of convincing and changing worldviews. The city was swollen from the arbitrariness, and over the Donetsk Region House the tricolor and the flag of the DPR loomed. The science of guardsmen Turk learned for life, "They were all together, for a long time was beating with legs. Then they raised, already blooded, set on a bench. Searched, pulled out a purse and a mobile. A redhead found the car keys in the bag and enjoyed". ${ }^{32}$ The robbery of peaceful population by "folk guardsmen" was regarded as replenishing the stocks of a young republic, but attempts to leave the city - as an escape, which could even shoot.

In the novel the author described views on Maidan and ATO from different positions: perception on the peaceful territory and residents of Donbass. "Max wanted to kill for revenge, and Vasia again felt the call of the blood of the original ancestors, which more than half a century ago were hidden in the glare and beat Muscovites, defending the right of Ukraine for existence". ${ }^{33}$

Consequently, the novel of Yulia Iliukha "Eastern Syndrome" tells the reader about the preconditions and the beginning of the RussianUkrainian war in the Donbass. Biographies of the main characters are a peculiar explanation for understanding global events. The author emphasizes not in the war that has devastating consequences, but on the lives of people who received a psychological injury while on the front.

30 Ілюха Ю. Східний синдром : роман. Харків : Книжковий клуб «Клуб сімейного дозвілля», 2019. С. 42.

${ }^{31}$ там само. С. 68.

32 там само. С. 73.

33 Ілюха Ю. Східний синдром : роман. Харків : Книжковий клуб «Клуб сімейного дозвілля», 2019. С. 84. 


\section{CONCLUSIONS}

The theme of the dignity revolution is quite wide and multifaceted. The writers were among the activists, the first tried to describe the events of Euromaidan trully. The literary process after the turning point in 2014 is actively replenished with journalistic and artistic works. The circle of writers expands and covers professional writers, journalists, bloggers, activists and volunteers. Favorable genres are reportage, interviews with eyewitnesses, investigation. In addition to journalistic and documentary works, a modern literary process is refilled with artistic: poetry and novels. Reproducing events of the revolution of dignity, authors resort to different methods. Some pages of their works focus on the chronology and geography of Maidan, the others deepen into the inner world of the main characters. The issue of the quality of the artistic work of authors remains problematic today, because the main emphasis was on a quick response about events, and not in the future.

The novel of the modern Ukrainian writer Luco Dashvar "The Cover" is a multifaceted, rises the problems of patriotism, loyalty of duty, and love, betrayal, human values. The author uses elements of mythopoetics, national history, intertwines the past with the modern. The main characters are changing under the influence of the revolution. Luko Dashvar holds parallels with various historical events: the revolution of 1918, the First World War. The immersion in the past helps to find questions that are concerned about the modern generation, to understand the mood of activists whose rows were actively replenished by young people. The heroes remain faithful to their ideals, because the most important value of man is freedom of will. Quite frequently the author resorts to binary oppositions, such as life and death, own and alien. Knowledge of one's roots, the reverence of ancestors helps to stand in the most difficult situations, because then the native blood becomes cover, protection.

The theme of Euromaidan and the beginning of the Russian-Ukrainian war in the Donbass is interesting in the novel of Yulia Iliukha "Eastern Syndrome". However, according to the author's definition, it is present, but not the main. Historical and social events the writer submits through the prism of the psychological consequences of "eastern syndrome". The work is an art fiction, written in view of real facts, and the main characters have their prototypes. Yulia Iliukha depicts radically opposite personalities, to men gives feminine features, and to women - on the contrary. Events on the Maidan heroes perceived indifferent firstly, until they touched them. It seems not everyone is aware of the seriousness and scale of the war. For Turk it became an instrument of revenge, for Lawyer - an escape from 
routine life, for Rock - the search for real herself. The author focuses on the psychological change of characters, their strength to return to peaceful life, overcome "eastern syndrome".

\section{SUMMARY}

The influence of the revolution of dignity on the development of modern Ukrainian literature was investigated, since Maidan became the basis for the formation of its genre variety. Prose works suffered significant transformation: from notes, blogs, comments in social networks to memoir literature and novels. Reproducing events of the revolution of dignity, authors resort to different methods. Some pages of their works focus on the chronology and geography of Maidan, the others deepen into the inner world of the main characters.

The composite features of Luco Dashvar's novel "The Cover" were defined and the role of the Maidan in determining the vital guidelines of the main characters was considered. The work is multifaceted, rises the problems of both patriotism, loyalty to duty, and love, betrayal, human values. The author uses elements of mythopoetics, national history, intertwines the past with the modern. The artistic world of the novel "Eastern syndrome" by Yulia Iliukha is analyzed and characterized Maidan as a precondition for the Russian-Ukrainian war in the Donbass. Historical and social events the writer submits through the prism of the psychological consequences of "eastern syndrome". The work is an art fiction, written in view of real facts, and the main characters have their prototypes.

\section{References}

1. Бахтин М. Формы времени и хронотопа в романе : Очерки по исторической поэтике. Москва : Просвещение, 1989. 360 с.

2. Герасименко Н. Історія з жіночим обличчям (огляд романів українських письменниць про події Революції гідності та війну на Сході України). Проблеми сучасного літературознавства. 2019. Вип. 29. С. 79-93.

3. Дашвар Люко. Покров : роман. Харків : Книжковий клуб «Клуб сімейного дозвілля», 2016. 384 с.

4. Ілюха Ю. Східний синдром : роман. Харків : Книжковий клуб «Клуб сімейного дозвілля», 2019. 240 с.

5. Майдан у книжках. URL: https://vsiknygy.net.ua/ shcho_pochytaty/36415/.

6. \#Під_Арсенал. Юлія Ілюха: ««Східний синдром» - це вигадана історія, яка перегукується з долями тисяч ветеранів ATO». URL: https://blog.yakaboo.ua/ru/shidnyi-syndrom/. 
7. Поліщук Я. Ефект Євромайдану і література. Слово $i$ час. 2015. № 10. С. 3-17.

8. Поліщук Я. Література майданного гарту. Літературний процес : методологія, імена, тендениії : збірник наукових праць (філологічні науки). 2015. № 6. С. 172-176.

9. Пухонська О. Посттоталітарна пам'ять у сучасній літературній інтерпретації: українська версія. Науковий вісник Ужгородського університету. Серія «Філологія». 2016. Вип. 2 (36). C. 214-218.

10.Сім книг про Майдан i Війну. Ще не осмислення, але ретельна фіксація реальності. URL: https://texty.org.ua/articles/ 62544/Sim_knyg_pro_Majdan_i_Vijnu_Shhe-62544/.

11.Словник української мови : Академічний тлумачний словник (1970-1980). URL: http://sum.in.ua/s/pokrov.

12. Чушенко Ю. Концепція особистості жінки в сучасній постмодерній прозі : дипломна робота. URL: http://93.183.203.244:80/xmlui/handle/ 123456789/6438.

13. Юлія Ілюха : «Письменники бувають і живими». URL: https://2day.kh.ua/yuliya-ilyuha-pismenniki-buvayut-i-zhivimi.

\section{Information about the authors:}

Kobylko Nataliia Andriivna,

Candidate of Philological Sciences, Senior Lecturer at the Department of Social-Humanitarian Disciplines of the Faculty № 6 Kharkiv National University of Internal Affairs 27, Lva Landau avenue, Kharkiv, 61080, Ukraine

Honcharuk Oleg Mykolaiovych, Candidate of Philological Sciences, Associate Professor at the Department of Foreign Languages of the Faculty № 1

Kharkiv National University of Internal Affairs 27, Lva Landau avenue, Kharkiv, 61080, Ukraine 